\title{
Li firewood dance studies in college education
}

\author{
Ouyang Xiao-qin \\ QiongZhou University \\ Art College \\ Sanya, China \\ 516093068@qq.com
}

\begin{abstract}
Education is one of the most important ways to protect heritage and to establish an effective transmission mode, $\mathrm{Li}$ firewood dance be introduced into school education and protection of heritage, not only for non-material cultural heritage opens a new path, while strengthening the school multicultural education, to promote cultural consciousness of the people, safeguard national cultural safety plays an important role.
\end{abstract}

\section{Keywords- firewood dance; teach; heritage}

\section{INTRODUCTION}

$\mathrm{Li}$ firewood folk dance is the most representative dances, Li language called "turn brake", "too brake." It originated in ancient cliff region (today in Sanya City, Hainan Province) $\mathrm{Li}$ funeral customs. Li firewood dance is the oldest and one of the most popular kinds of dance. Li phrase "turn brake", originated in ancient cliff $\mathrm{Li}$ funeral activities, the Department of $\mathrm{Li}$ ancient people used to guard the corpse when dead, off the beast, appease and worship of a funeral dance. May 20, 2006, the State Council approved the Li firewood dance included in the first batch of national intangible cultural heritage.

\section{OVERVIEW OF FIREWOOD DANCE}

\section{A. Firewood dance origins}

$\mathrm{Li}$ firewood questions about the origins of the current academic dance in two different ways: First, it originated in an ancient ritual activities, with a strong religious overtones of the original, after the death of $\mathrm{Li}$ ancestors to protect the body, driving the beast, and pay homage to their loved ones an ancestor funeral dance. "Hainan Li firewood folk dance is the most representative dances, Li family also called 'jump firewood', Li language called 'turn brake' or 'card slightly', originated in ancient cliff region (today in Sanya City, Hainan Province ) for funerals. "Second, Hainan dance scholar Mr. Wu Minghui considered firewood dance is" lost bamboo hut built up from time to time when to slide down from the roof, people meet in order to avoid playing foot barbed face, they danced jump from time to time, it is imitate and improve gradually, forming a 'jump wood'. "

\section{B. Development and evolution of firewood dance}

The template is used to format your paper and style the text. All margins, column widths, line spaces, and text fonts are prescribed; please do not alter them. You may note peculiarities. For example, the head margin in this template measures proportionately more than is customary. This measurement and others are deliberate, using specifications that anticipate your paper as one part of the entire proceedings, and not as an independent document. Please do not revise any of the current designations.

\section{Firewood dance facing a crisis of survival}

Due to the changing times and the living environment of the development of modern society is facing a crisis of survival firewood dance. According to the author on the part of schools and colleges in Sanya City, Hainan students to do a survey: At present, Hainan young little dance can jump firewood, firewood understand the culture and history of dance is minimal, to see the fight Chai dance only in tourist attractions and sports classes in some schools, with the older generation of firewood dance heritage of passed away, facing heritage fault. Since Li firewood dance has been included in the first batch of national intangible cultural heritage list, then how to make the intangible cultural heritage and to protect this dynamic, heritage, promote, every concern the development of Hainan $\mathrm{Li}$ dance culture dance work by those who should be thinking.

\section{THE NEED FOR SCHOOLS TO INTRODUCE FIREWOOD DANCE HERITAGE}

I believe that will be introduced into firewood dance school education (including primary and secondary music, physical education, and public colleges and universities music, physical education), the school became firewood dance heritage and the protection of cultural heritage and stable place to play in the school teachers to teach Chai dance, students learn firewood dance, teaching and learning, for $\mathrm{Li}$ firewood dance heritage and protection has an important role. Secondly, Li introduced into firewood dance school education is conducive to resolving the plight of the modern inheritors Li firewood dance facing faults, school teachers have a more stable and students through the school's firewood dance education, master Li firewood dance skills of teachers, assisted by firewood dance audiovisual materials and other teaching tools, will be able to take up the heritage of its capability to Li firewood dance task. Part of the dance students are particularly interested in firewood future is likely to be the inheritor of firewood dance, and this impact is profound heritage. Since firewood music and dance students have the physical ability of the double effect, 
therefore firewood dance into the campus multicultural education for schools to carry out, to create a good cultural environment on campus, has an important significance to speed up music lessons, sports curriculum reform so smooth progress .

A. Firewood dance into the campus, meet the music, sports curriculum reform objective needs

Music curriculum standards important values is to "promote national music, multicultural understanding," $\mathrm{Li}$ firewood dance on the one hand has a rich history and cultural heritage, the music sounds beautiful, strong sense of rhythm, in line with students' psychological needs ; hand movement change Multiport enable students to fully experience the "Music is the soul of dance ", the rhythm, the students can create invention can effectively mobilize the enthusiasm of students, for students with learning initiative

The author of the different levels of school physical education survey found that : "A whistle two balls, such as ringtones shade below " is widespread, sports qualities classroom, no professional requirements, no pressure, monotonous teaching content, teachers and students is certainly no interest and just ; then how to change this phenomenon, so that the quality of physical education really achieve the purpose of enhancing people's physique, I think changing the teaching contents and methods are particularly important. Why Modern Aerobics, Cheerleading popular is because there is a dynamic musical accompaniment, while $\mathrm{Li}$ firewood dance with the musical accompaniment of positive physical effects, coordinating training of students in the entertainment, aesthetic, focus, thinking capabilities, while students also the spirit of unity and cooperation to achieve a multiplier effect heritage ..

\section{B. School teaching dance heritage firewood, non-material} cultural heritage to explore ways beneficial

Culture is the spirit and soul of a nation, is a powerful force for national development and national rejuvenation . With the impact of changes in global economic integration and cultural environment and other conditions, the existence of non-material cultural heritage as a form of culture, education is one of the most important ways heritage and conservation. The United Nations ' Convention on the Safeguarding of the Intangible Cultural Heritage " Intangible cultural heritage can be used" through formal and non-formal education " to achieve. Hu Kai in " Musical Heritage Intangible Cultural Heritage Education fulcrum - based curriculum," an article describes the musical heritage of Intangible Cultural Heritage Education significance of three points : First, clear the student is the main heritage, the second is clearly the heritage the content is excellent location music intangible Cultural Heritage, the third is passed through into and out of the classroom in the form of providing a diverse educational heritage channels.

If part of the endangered intangible cultural heritage be introduced into school education and heritage protection, the establishment of an effective mode of inheritance, the nonmaterial cultural heritage heritage open a new path, but can also broaden multicultural school curriculum, so that the content of school education and the protection of intangible cultural heritage combine to promote the development and prosperity of the national culture and enhance national cultural soft power .

\section{THE FEASIBILITY OF INTRODUCING SCHOOL DANCE HERITAGE OF FIREWOOD}

\section{A. Institutional guarantees}

"Basic Education Curriculum Reform (Trial ) ", issued in 2001 pointed out that while the implementation of the national curriculum in schools and local programs, depending on the specific circumstances should the local social and economic development, and the advantages of combining traditional school, students' interests and needs, development or selection of appropriate school curriculum . Issued documents to provide a security policy and institutional development of the school curriculum resources for teaching subjects . Subject to specific aspects of " fulltime compulsory music curriculum standards (trial version ) " and " full-time compulsory physical education and health curriculum standards (trial version ) " provides national curriculum courses account for $80 \%-85 \%$ of total local self-development courses and schools account for $15 \%$ $20 \%$. Local and school music, physical education should be combined with the local environment and cultural traditions of human geography, to carry music, physical education curriculum with regional, national and school characteristics. Firewood dance heritage not only solve the problem of course, but to make up for the shortcomings of the national curriculum. Make full use of local resources across schools, according to the region and the characteristics of students, the development of local music, physical education curriculum with distinct characteristics, both to facilitate the students to improve in music and physical fitness, but also to meet the individual needs of students .

The above series of curriculum reforms enacted in music, sports and other documents curriculum standards and implementation, the introduction of the current teaching of music in our country provides a powerful system for firewood dance guaranteed.

\section{B. Implementation of some schools to provide firewood dance into the campus experience guarantee}

According to my investigation at present, Hainan Overseas Chinese School, Guoxing high school, middle school national Sanya, Sanya First School, Shaw Middle School in Sanya, Hainan Normal University, talks about college, Sanya College and other schools have introduced the firewood to the school dance music, physical education curriculum teaching. The move full description of these schools will introduce firewood dance to the music teaching in schools is feasible . Especially in 2012 organized by the Education Department of Hainan Province, Hainan Province Students bamboo dance contest, Hainan Province, secondary vocational schools Bamboo Dance Competition 2013 organized by the Hainan Provincial Department of Education for firewood dance into the campus has laid a good foundation, and as firewood dance heritage and the 
protection provided valuable experience for the preparation of the specific implementation methods, teacher training, curriculum and other teaching materials designed firewood dance teaching provides a useful reference. At the same time, to carry firewood dance venues and equipment for teaching is not much to ask too much, more convenient to implement . Especially in Hainan has a cultural tradition firewood dance, just dance will be firewood local curriculum and schoolbased curriculum development, teacher training, teachers in the implementation process according to the specific materials and lesson plans, to understand the origins of firewood dance, culture content, supplemented by firewood dance audiovisual materials and other teaching tools, will be able to train students, to promote students' musical aesthetic ability, physical coordination, and improve their ability to innovate, develop good teamwork ability.

\section{EFFECTIVENESS OF FIREWOOD DANCE EDUCATION}

\section{A. Firewood dance music aesthetic ability to cultivate students with attention}

The firewood is introduced to the school dance music teaching activities, not only can change the teaching of traditional music boring, boring drawbacks, by students, "firewood" and "jump firewood," the United States and feel the music, dance and enjoy beauty, enhanced aesthetic appeal. In the course of the completion of the dance firewood, firewood firewood were necessary to pay attention to their own rhythm of the percussion, the master division Tap scale; Second, pay attention to the rhythm and height changes when firewood; Third, we must protection of firewood by jumping to avoid serious injury when caught. Who should pay more attention to jump firewood rhythm; choose fit well with the position change companion action, grasp the dance. "Firewood" and "jump firewood" cooperate with each other, not only the students' ability to exercise coordination body, but also the attention of students, and enhance the beauty of dance music sensibility and ability.

\section{B. Firewood dance can improve student teamwork, ability to learn from each other}

Firewood dance is a collective activity that requires firewood and firewood were co-hop, especially when people jump firewood, we must unite as one, according to the beat on the need concerted action in order to interpret success.

Firewood dance moves from easy to difficult, from slow to fast-paced, and the role of firewood and firewood are often jumping mutual conversion. This constant conversion, but also to foster collaboration and the ability of students to learn from each other, can put themselves in consideration for each other, to learn from each other's experiences and help each other in case of conflict with repeated with others to jump together with the successful completion of firewood firewood action. Therefore, the introduction of firewood learning dance not only help improve the students 'teamwork, better able to improve students' ability to learn from each other through firewood dance to learn.

\section{Firewood dance can improve students' creative thinking ability}

Essence of all learning is to create, whether it is personal or for development of the country have an important role. Firewood hop dance school started relatively simple, because it is not difficult rhythm, jump method is very simple, but if further add some more difficult skills to master more difficult. In the specific teaching, can teach students basic firewood dance rhythms and dance, and then let the students play their own initiative and creative thinking, according to their own understanding of firewood dance choreography creative action, which directed the play wood dance for students' creative thinking, further reform and innovation firewood dance is important.

\section{Firewood dance can enhance students' national self- confidence}

Cultural traditions of a nation generations of spiritual wealth, endless constant source of national development. Cultural traditions can develop students' self-esteem and inspire the spirit of national self-reliance, so that national rebirth. Firewood dance in traditional Chinese culture is an excellent representative, its national unity and national selfconfidence improved, the socialist spiritual civilization and the construction of campus culture plays an important role.

\section{SUMMARY}

The introduction of the current firewood dance school education which, without increasing the burden on students, and reasonably curriculum resource development is not only necessary, but also feasible. Such protection is not just for firewood dance heritage of great significance, but also a useful attempt on the protection of intangible cultural heritage and schooling organic combination.

\section{ACKNOWLEDGMENT}

This research was financially supported by The Hainan Planning projects of philosophy and Social Sciences (No. HNSK(GJ)-153); National study base in Hainan Province in 2011 planning issues (No.QMZJD2012-16); The Project of Undergraduate Practice Teaching Reform Project in QiongZhou University (No. QYSJ2013-080).

\section{REFERENCES}

[1] Yue Yong-jie, “Anthropological Study of Education in Hainan Li firewood dance cultural heritage”, in Minzu University of China, 2008.

[2] Guo Lu-lu, "The Inheritance and Development of the $\mathrm{Li}$ DachaiDance”, in Journal of Guizhou University(Art Edition),2009, vol 02, pp. :86-88.

[3] Cai Dao-cheng Zhang Qiao,”Analysis of the Channels to Teacher Professionalization”, Journal of Qiongzhou University, 2010, vol 17,pp. 20-21.

[4] Zhan Xian-wu,"Hainan Intangible Cultural Heritage Introduction (3) Li firewood dance”, in The New Orient, 2008,vol 08, pp. 67.

[5] Wang Quan-hong,” The Origin and Evolution of the Dance of Li Nationality",in Journal of Hainan Radio \& TV University, 2011vol .03, pp. 57-59. 
[6] Jia Zhu,"University Digital Piano the Innovation of Teaching Methods and Practice”, in Key Engineering Materials. Vols. 474-476, pp 1899-1902. 2011.

[7] Ma Xiao-li,” Analysis of Hainan Li folk dance evolution”, in Journal of Hainan Radio \& TV University, 2019,vol 04, pp. 25-27.

[8] Jia Zhu,” Multimedia Music Teaching System Application”, in Key Engineering Materials”, Vols. 474-476, pp 1903-1908.2011.
[9] Jia Zhu,"MIDI and Music Teaching in Colleges of Multimedia System Application", in Key Engineering Materials. Vols. 474-476, pp 1926-1930.2011.

[10] Zhu Jia,"Study on National Cultural Structure of Li Nationality Traditional Music Form in HaiNan", in Information Engineering Research Institute. Vols. 2, pp 385-38.2012. 